\title{
ANALISIS PENGARUH PELATIHAN TERHADAP KINERJA PEGAWAI PADA SUB BAGIAN KEUANGAN DINAS PEKERJAAN UMUM DAN PENATAAN RUANG KABUPATEN LAMPUNG SELATAN
}

\author{
Pungki Handoko ${ }^{(1)}$, Hazairin Habe ${ }^{(2)}$, Kuswarak $^{(2)}$ \\ Fakultas Ekonomi Universitas Sang Bumi Ruwa Jurai \\ handoko_puungki@gmail.com,hazairin.habe@fe.saburai.ac.id,kuswarak@fe.saburai.ac.id
}

\begin{abstract}
Abstrak. Tujuan penelitian ini adalah untuk mengetahui pengaruh pelatihan terhadap kinerja pegawai pada Sub Bagian Keuangan Dinas Pekerjaan Umum dan Penataan Ruang Kabupaten Lampung Selatan. Jenis penelitian adalah kuantitatif. Populasi yang dimaksud disini adalah pegawai Sub Bagian Keuangan Dinas Pekerjaan Umum dan Penataan Ruang Kabupaten Lampung Selatan sebanyak 35 orang pegawai. Sampel yang digunakan adalah sampel jenuh, dimana semua populasi dijadikan sampel, yaitu sebanyak 35 orang pegawai. Pengumpulan data menggunakan kuesioner. Analisis kuantitatif untuk menguji hipotesis asosatif (pengaruh antar variabel) menggunakan pendekatan Analisis Regresi Linier Sederhana. Ada pengaruh pelatihan terhadap kinerja pegawai Sub Bagian Keuangan Dinas Pekerjaan Umum dan Penataan Ruang Kabupaten Lampung Selatan, dimana berdasarkan uji-t didapatkan nilai thitung yaitu $=3,558$. Apabila dibandingkan dengan tTabel pada taraf nyata $95 \%$ dan $\alpha=0,05$ yaitu 1,697 maka thitung $=3,558>$ tTabel $=$ 1,697. Hasil penelitian menunjukkan persamaan regresi $\mathrm{Y}=23,991+0,395 \mathrm{X}$, persamaan tersebut menunjukkan bahwa jika terjadi peningkatan variabel pelatihan sebesar 1 satuan maka kinerja akan meningkat sebesar 0,395 , Sedangkan besarnya pengaruh pelatihan diketahui melalui penghitungan koefisien determinasi $\left(\mathrm{r}^{2}\right)=27,7 \%$, artinya kinerja pegawai dipengaruhi $27,7 \%$ oleh pelatihan. Hasil dari penelitian ini adalah terdapat pengaruh pelatihan terhadap kinerja pegawai Sub Bagian Keuangan Dinas Pekerjaan Umum dan Penataan Ruang Kabupaten Lampung Selatan.
\end{abstract}

Kata kunci: Kinerja, Pegawai, Pelatihan, Regresi.

\section{PENDAHULUAN}

Berkembangnya manajemen sumber daya manusia di era globalisasi saat ini menjadi upaya untuk meningkatkan kualitas dalam bekerja. Para pegawai selalu diharapkan dapat bekerja secara produktif dan professional sehingga kinerja yang dicapainya akan lebih memuaskan sesuai standar kerja yang dipersyaratkan. Sumber Daya Manusia (SDM) adalah faktor yang mempengaruhi dalam suatu organisasi. Apapun bentuk serta tujuannya organisasi dibuat berdasarkan berbagai visi dan misi untuk kepentingan manusia dan dalam pelaksanaan misinya dikelola oleh manusia agar tercapainya tujuan yang telah ditentukan.
Manajemen sumber daya manusia adalah suatu proses menangani berbagai masalah pada ruang lingkup karyawan, pegawai, buruh, manajer dan tenaga kerja lainnya untuk dapat menunjang aktifitas organisasi atau perusahaan demi mencapai tujuan yang telah ditentukan. Saat ini manajemen sumber daya manusia berubah dan fungsi spesialisasi yang berdiri sendiri menjadi fungsi yang terintegrasi dengan seluruh fungsi lainnya di dalam organisasi, untuk bersama-sama mencapai sasaran yang sudah ditetapkan serta memiliki fungsi perencanaan yang sangat strategik dalam organisasi, dengan kata lain fungsi sumber daya manusia lama menjadi lebih bersifat strategik.

Manajemen sumber daya manusia mempunyai kewajiban untuk memahami 
perubahan yang semakin komplek yang selalu terjadi di lingkungan bisnis, harus mengantisipasi perubahan teknologi, dan memahami dimensi internasional yang mulai memasuki bisnis akibat informasi yang berkembang cepat.

Kemampuan para pegawai harus di berdayakan melalui salah satunya pelatihan, oleh karena itu pelatihan merupakan setiap usaha untuk memperbaiki sikap pekerja pada suatu pekerjaan tertentu yang sedang menjadi tanggungjawabnya, atau satu pekerjaan yang ada kaitannya dengan pekerjaannya. Dengan demikian istilah pelatihan ditujukan kepada pegawai pelaksanaan dalam rangka meningkatkan pengetahuan dan keterampilan teknis.

Berdasarkan hasil penelitian awal di Dinas Pekerjaan Umum dan Penataan Ruang Kabupaten Lampung Selatan, masih terdapat masalah yang memperlihatkan rendahnya kinerja pegawai terlihat dari indikator-indikator kinerja sebagai berikut: Kualitas kerja (Quality of work) bahwa hasil kerja yang memenuhi keinginan dan tanggungjawab yang merupakan bagaian dari tujuan organisasi. Ketepatan waktu (Promptness) bahwa waktu penyelesaian pekerjaan dengan target waktu yang direncanakan. Contoh : Masih ada beberapa pegawai yang tidak datang tepat waktu yaitu Pukul 07.30, dan pada saat jam kerja berlangsung banyak pegawai yang tidak ada ditempat (kantor). Peneliti menemukan pegawai di Dinas Pekerjaan Umum dan Penataan Ruang Kabupaten Lampung Selatan pada saat bekerja tidak ada di kantor sehingga menghambat pencapaian tujuan yang ada dan hasil yang dicapai belum maksimal.

Berdasarkan permasalahanpermasalahan tersebut di atas, belum tercapainya kinerja pegawai disebabkan kurangnya pelatihan yang masih banyak belum dilaksanakan dengan karakteristik sebagai berikut: Tidak jelasnya tujuan dan sasaran dalam melaksanakan pelatihan agar para pegawai bisa lebih terlatih untuk melakukan segala tugas dengan baik. Contoh: Melaksanakan pelatihan jabatan atau latihan prajabatan masih belum tersampaikannya sasaran yang harus dicapai oleh peserta latihan sehingga hasil dari pelatihan yang dilakukan tidak berjalan optimal.

Dengan tidak tersampaikannya sasaran dari pelatihan yang dilaksanakan mengakibatkan tujuan yang ada di Dinas Pekerjaan Umum dan Penataan Ruang Kabupaten Lampung Selatan belum terlaksana dengan baik. Minimnya materi dalam pelatihan yang ditujukan kepada pegawai. Contoh: kurangnya materi pelatihan untuk para pegawai sehingga pegawai masih saja ada yang kurang memahami tugas yang akan dicapai. Peneliti menyimpulkan kurangnya materi yang diberikan oleh para pelatih sehingga para pegawai masih kurang efisien dalam melaksanakan tugas.

Berdasarkan uraian di atas, maka peneliti tertarik untuk mengadakan penelitian yang berjudul: "Analisis Pengaruh Pelatihan Terhadap Kinerja Pegawai Pada Sub Bagian Keuangan Dinas Pekerjaan Umum dan Penataan Ruang Kabupaten Lampung Selatan".

\section{KAJIAN TEORI}

\section{Manajemen Sumber Daya Manusia}

Sumber daya manusia merupakan salah satu unsur input sama dengan unsur input lainnya seperti modal, mesin, bahan mentah dan teknologi yang diubah melalui proses produksi menjadi output berupa barang atau jasa. Manajemen sumber daya manusia merupakan bagian dari manajemen, dimana manajemen sumber daya manusia ini menitikberatkan perhatiaannya pada masalah-masalah manusia dalam hubungan kerja dengan tugas- tugasnya tanpa 
mangabaikan faktor-faktor produksi lainnya.

Pelaksanaan pemberian insentif dan motivasi dalam rangka meningkatkan kinerja adalah suatu aspek dari manajemen sumber daya manusia, untuk itu perlu diketahui definisi atau pengertian dari manajemen sumber daya manusia untuk dapat lebih memahami maksud dan tujuan dari penelitian ini.

Pengertian manajemen sumber daya manusia menurut Sadili Samsudin (2013) mengemukakan bahwa: Manajemen sumber daya manusia merupakan aktivitas-aktivitas yang dilaksanakan agar sumber daya manusia dalam organisasi dapat didayagunakan secara efektif dan efisien guna mencapai berbagai tujuan.

Sedangkan pengertian manajemen sumber daya manusia menurut Hasibuan, Malayu S.P (2009) adalah: "Ilmu dan seni mengatur hubungan dan peranan tenaga kerja agar efektif dan efisien membantu terwujudnya tujuan perusahaan, karyawan, dan masyarakat".

Pendapat lain mengenai definisi manajemen sumber daya manusia menurut Veithzal Rivai dan Ella Jauvani (2015) mengemukakan bahwa: "Manajemen sumber daya manusia (MSDM) merupakan kumpulan pengetahuan tentang bagaimana seharusnya memanage (mengelola) sumber daya manusia yang meliputi segi-segi perencanaan, pengorganisasian, pelaksanan, dan pengendalian fungsi produksi, pemasaran, maupun kepegawaian dalam pencapaian tujuan perusahaan". Sedangkan pengertian manajemen sumber daya manusia menurut Hasibuan (2013:97) adalah "ilmu dan seni mengatur hubungan dan peranan tenaga kerja agar efektif dan efisien membantu terwujudnya tujuan perusahaan, pegawai, dan masyarakat”.

Berdasarkan berbagai definisi para ahli manajemen sumber daya manusia di atas dapat disimpulkan bahwa manajemen sumber daya manusia adalah suatu proses yang dilakukan oleh atasan untuk memperoleh, mempertahankan, dan mengembangkan tenaga kerja, baik dari segi kualitas maupun kuantitas agar tenaga kerja dapat didayagunakan secara efektif dan efisien guna mencapai tujuan perusahaan. Fokus sumber daya manusia adalah masalah tenaga kerja manusia, yang diatur menurut perpaduan fungsi manajemen dengan fungsi operasional SDM diantaranya planning, organizing, actuating, dan controlling, dalam melaksanakan kegiatan recruitmen, development, maintenance, integration, separation agar efektif dan efisien dalam mewujudkan tujuan perusahaan, pegawai, dan masyarakat.

\section{Pengertian Pelatihan}

Berikut ini beberapa definisi yang dikemukakan para ahli mengenai pelatihan: Menurut Sumarsono (2013) pelatihan merupakan salah satu faktor yang penting dalam pengembangan SDM. Pendidikan dan latihannya tidak hanya menambah pengetahuan, akan tetapi juga meningkatkan keterampilan bekerja, dengan demikian meningkatkan produktivitas kerja.

Menurut Flippo dalam Hasibuan (2013): Training is the act of increasing the knowledge and skill of an employee for doing particular job. Definisi ini menjelaskan bahwa latihan merupakan suatu usaha untuk peningkatan pengetahuan dan keahlian seorang karyawan untuk mengerjakan suatu pekerjaan tertentu. Selanjutnya menurut Atmodiwirio (2013) menguraikan : "Pelatihan adalah pembelajaran yang dipersiapkan agar pelaksanaan pekerjaan sekarang meningkat (kinerjanya). Pelatihan menurut konsep lembaga Administrasi menekankan pada proses peningkatan kemampuan seorang individu dalam melaksanakan tugasnya" 
Menurut Fandy \& Anastasia (2013) Pelatihan merupakan bagian dari pendidikan. Pendidikan lebih bersifat filosofis dan teoritis. Walaupun demikian, pelatihan memiliki tujuan yang sama, yaitu pembelajaran. Di dalam pembelajaran terdapat pemahaman secara implinsit. Melalui pemahaman, karyawan dimungkinkan untuk menjadi seorang inovator, pengambilan inisiatif, pemecahan masalah yang kreatif, serta menjadikan karyawan efektif dan efesien dalam melakukan pekerjaan.

Pendidikan dan pelatihan merupakan upaya untuk mengembangkan sumber daya manusia, terutama untuk mengembangkan kemampuan intelektual dan kepribadian manusia. Penggunaan istilah pendidikan istilah pelatihan dalam suatu institusi atau organisasi biasanya disatukan menjadi diklat (pelatihan) (Soekidjo, 2013). Sjafri (2013) mendefinisikan pelatihan bagi karyawan merupakan sebuah proses mengajarkan pengetahuan dan keahlian tertentu serta sikap agar karyawan semakin terampil dan mampu melaksanakan tanggung jawabnya dengan semakin baik, sesuai dengan standar.

Menurut (Wahyudi, 2013) : "Pelatihan dan pengembangan merupakan usaha menghilangkan terjadinya kesenjangan (gap) antara unsur-unsur yang dimiliki oleh seorang tenaga kerja dengan unsurunsur yang dikehendaki organisasi. Usaha tersebut dilakukan melalui peningkatan kemampuan kerja yang dimiliki tenaga kerja dengan cara menambah pengetahuan dan ketrampilannya". Pelatihan atau dengan istilah "training" merupakan salah satu program perusahaan yang strategis dalam rangka mempertahankan dan memberikan motivasi kepada karyawan (Ahmad, 2013).

Dari beberapa definisi mengenai pelatihan dapat disimpulkan bahwa:
1. Pelatihan dapat meningkatkan pengetahuan, kemampuan, keahlian, sikap dan perilaku serta kinerja karyawan.

2. Pelatihan berhubungan dengan pekerjaan tertentu yang harus dilakukan dalam perusahaan.

\section{Tujuan Pelatihan}

Menurut Wahyudi (2013) sebagai tujuan umum, suatu program pelatihan dan pengembangan yang dilaksanakan harus diarahkan untuk meningkatkan efektivitas dan efisiensi organisasi. Tujuan ini dapat tercapai apabila tujuantujuan yang bersifat khusus dapat diwujudkan terlebih dahulu. Tujuan khusus dari program pelatihan dan pengembangan antara lain :

1. Meningkatkan produktivitas

Pelatihan tidak hanya ditujukan untuk tenaga kerja yang masih baru, tetapi juga tenaga kerja lama. Ini dimaksudkan untuk membantu meningkatkan kemampuan tenaga kerja yang bersangkutan dalam melaksanakan tugasnya.

2. Meningkatkan kualitas

Meningkatnya kualitas produksi, memperkecil kemungkinan kesalahan yang dilakukan pekerja, sehingga kualitas output diharapkan juga meningkat.

3. Meningkatkan mutu perencanaan tenaga kerja

Perencanaan tenaga kerja dan program pelatihan tidak dapat dipisahkan, karena organisasi selalu merencanakan kebutuhan tenaga kerja secara kuantitatif dan kualitatif, baik untuk sekarang maupun untuk masa yang akan datang. 
4. Meningkatkan semangat tenaga kerja Program pelatihan akan memperbaiki iklim dan mengurangi ketegangan yang terjadi di dalam organisasi, sehingga akan menimbulkan reaksi positif dari tenaga kerja yang bersangkutan.

5. Sebagai balas jasa tidak langsung Dengan memberikan kesempatan untuk mengikuti program pelatihan kepada seseorang tenaga kerja, dapat diartikan sebagai pemberian balas jasa atas prestasinya di masa lalu.

6. Meningkatkan kesehatan dan keselamatan kerja

Pelatihan yang baik dapat mengurangi atau mencegah terjadinya kecelakaan kerja di dalam organisasi, sehingga menciptakan lingkungan kerja yang lebih aman dan memberikan ketenangan dan stabilitas pada sikap mental tenaga kerja.

7. Mencegah kadaluwarsaan

Pelatihan dapat mendorong inisisatif dan kreativitas tenaga kerja, sehingga dapat mencegah terjadinya sifat kadaluwarsaan tenaga kerja yang akan terjadi bila kemampuan yang dimilikinya tertinggal oleh kemampuan yang diperlukan sesuai dengan perkembangan teknologi.

8. Kesempatan pengembangan diri Pelatihan memberikan kesempatan bagi karyawan untuk meningkatkan pengetahuan dan kemampuannya, meningkatkan perkembangan kepribadiannya.

\section{Pengertian Kinerja}

Menurut Maryoto (2010) Kinerja pegawai adalah hasil kerja selama periode tertentu dibandingkan dengan berbagai kemungkinan, misal standar, target/sasaran atau kriteria yang telah disepakati bersama. Gibson (2006) menyatakan kinerja adalah hasil yang diinginkan dari perilaku. Kinerja individu merupakan dasar dari kinerja organisasi.

Penilaian kinerja mempunyai peranan penting dalam peningkatan motivasi ditempat kerja. Penilaian kinerja ini (performance appraisal) pada dasarnya merupakan faktor kunci guna mengembangkan suatu organisasi secara efektif dan efisien. Pegawai menginginkan dan memerlukan balikan berkenaan dengan prestasi mereka dan penilaian menyediakan kesempatan untuk memberikan balikan kepada mereka jika kinerja tidak sesuai dengan standar, maka penilaian memberikan kesempatan untuk meninjau kemajuan pegawai dan untuk menyusun rencana peningkatan kinerja (Garry Dessler, 2009).

Rahmanto (2010): Prestasi kerja atau kinerja sebagai tingkat pelaksanaan tugas yang bisa dicapai oleh seseorang, unit, atau divisi, dengan menggunakan kemampuan yang ada dan batasan-batasan yang telah ditetapkan untuk mencapai tujuan instansi.

\section{METODE PENELITIAN}

\section{Objek Penelitian}

Objek dalam penelitian ini adalah apartur pemerintah pada Dinas Pekerjaan Umum dan Penataan Ruang Kabupaten Lampung Selatan di Jalan Mustafa Kemal Nomor 21 Kalianda Lampung Selatan, penelitian akan dilaksankan pada bulan Maret 2017.

\section{Metode dan Teknik Pengumpulan Data}

Dalam penelitian ini jenis data yang diperlakukan adalah :

a. Data Primer 
Data primer merupakan data dasar yang akan diperoleh langsung tanpa perantara orang atau lembaga lain sebagai pihak ketiga. Data primer ini diperoleh dengan wawancara melalui responden dengan menggunakan daftar pertanyaan.

b. Data Sekunder

Data skunder merupakan data yang diperoleh melalui orang lain yang berhubungan dengan permasalahan yang dipecahkan. Data sekunder ini diperoleh melalui cara studi dokumenter yaitu mengumpulkan dan mempelajari brosurbrosur serta dokumen organisasi.

Adapun teknik yang digunakan dalam pengumpulan data adalah dengan :

1. Observasi, yaitu mengadakan survey atau pengamatan langsung kelokasi penelitian.

2. Interview atau wawancara, yaitu mengadakan tanya jawab langsung dengan pegawai Sub Bagian Keuangan Dinas Pekerjaan Umum dan Penataan Ruang Kabupaten Lampung Selatan.

3. Dokumentasi, yaitu mengumpulkan dan mencatat dokumentasi yang relevan.

4. Quisioner, yaitu membuat pertanyaan yang berhubungan dengan variabel penelitian.

\section{Sampel dan Populasi}

Penelitian yang menggunakan metode survey, tidak harus meneliti seluruh individu dalam populasi yang ada, karena akan membutuhkan biaya yang besar dan juga waktu yang lama. Penelitian dapat dilakukan dengan meneliti sebagian dari populasi (sampel), diharapkan hasil yang diperoleh dapat mewakili sifat atau karakteristik populasi yang bersangkutan. Populasi yang dimaksud disini adalah pegawai Sub Bagian Keuangan Dinas Pekerjaan Umum dan Penataan Ruang Kabupaten Lampung Selatan sebanyak 35 orang pegawai.

\section{Metode Analisis Data}

Analisa data adalah proses penyederhanaan data ke dalam bentuk yang lebih mudah dibaca dan dipahami serta diinterpretasikan melalui kalimat. Pada penelitian ini, analisa data yang digunakan adalah analisis data kualitatif dan analisis data kuantitatif.

Persamaan Regresi Linear Sederhana menentukan persamaan regresi linear sederhana untuk X :

$$
Y=a+b X+e
$$

Keterangan:

$$
\begin{aligned}
& \mathrm{Y}=\text { Kinerja pegawai } \\
& \mathrm{a}=\text { Konstanta } \\
& \mathrm{b}=\text { Koefisien regresi } \mathrm{X} \\
& \mathrm{X}=\text { Pelatihan } \\
& \mathrm{e}=\text { Faktor kesalahan }
\end{aligned}
$$

Untuk mengetahui besarnya pengaruh, penghitungan koefisien korelasi tersebut kemudian dilanjutkan dengan Rumus Koefisien Determinasi atau Koefisien Penentu (KP):

\begin{tabular}{|c|c|}
\hline$t_{\text {hitung }}$ & $=$ Nilai $\mathrm{t}$ \\
\hline$r$ & $=$ Koefisien Korelasi \\
\hline
\end{tabular}

$$
K P=(r)^{2} x 100 \%
$$

Untuk menguji secara hipotesis secara parsial digunakan Uji t dengan rumus :

$$
t_{\text {hitung }}=\frac{r \sqrt{N-2}}{\sqrt{1-r^{2}}}
$$

Keterangan: 
Kriteria untuk Uji $\mathrm{t}$ adalah sebagai berikut :

a) Jika $t_{\text {hitung }}>t_{\text {tabel }}$ maka Ha diterima dan Ho ditolak.

b) Jika $t$ hitung $\leq t$ tabel maka Ha ditolak dan Ho diterima.

\section{HASIL DAN PEMBAHASAN}

\section{Uji Validitas dan Uji Reliabilitas}

Suatu pernyataan dikatakan valid jika pertanyaan tersebut mampu untuk mengukur apa yang perlu diukur dan mampu mengungkapkan apa yang ingin diungkap. Pada penelitian ini, uji validitas yang digunakan adalah korelasi pearson. Uji validitas dilakukan untuk mengukur pernyataan-pernyataan yang ada dalam kuesioner. Uji validitas dilakukan dengan mengkorelasikan masing-masing skor pernyataan untuk mesing-masing variabel dengan skor total variabel. Selanjutnya angka korelasi yang dihasilkan akan dibandingkan dengan nilai rTabel pada $a=0,05$ yaitu sebesar 0,3388. Berdasarkan data dapat diketahui bahwa seluruh item skor pertanyaan yang tentang pelatihan dan kinerja memiliki nilai rhitung lebih besar dari $\mathrm{r}_{\text {Tabel }}=0,3388$. Dengan demikian keseluruhan item pertanyaan pelatihan tersebut valid dan dapat digunakan sebagai alat ukur penelitian.

Uji reliabilitas instrumen menggunakan rumus Cronbach Alpha $(\alpha)$ untuk masingmasing variabel adalah lebih besar dari 0,60 . Nilai reliabilitas konsistensi internal untuk koefisien Alpha Cronbach dinyatakan reliabel karena lebih besar dari 0,60. Dengan demikian item pengukuran pada masing-masing indikator dalam variabel-variabel penelitian dinyatakan reliabel dan selanjutnya dapat digunakan dalam penelitan.

\section{Analisis Kuantitas}

Berdasarkan hasil penelitian diperoleh data hasil uji-t didapatkan nilai thitung yaitu $=3,558$. Apabila dibandingkan dengan tTabel pada taraf nyata $95 \%$ dan $\alpha=0,05$ yaitu 1,697 maka thitung $=3,558>$ tTabel $=1,697$ sehingga dapat disimpulkan bahwa: Ho yang menyatakan tidak terdapat pengaruh antara Variabel $\mathrm{X}$ (pelatihan) terhadap variabel Y (kinerja) Pegawai Sub Bagian Keuangan Dinas Pekerjaan Umum dan Penataan Ruang Kabupaten Lampung Selatan diterima dan Ha yang menyatakan terdapat pengaruh antara Variabel $X$ (pelatihan) terhadap variabel Y (kinerja) Pegawai Sub Bagian Keuangan Dinas Pekerjaan Umum dan Penataan Ruang Kabupaten Lampung Selatan ditolak.

Hasil penelitian menunjukkan persamaan regresi $\mathrm{Y}=23,991+0,395 \mathrm{X}$, persamaan tersebut menunjukkan bahwa jika terjadi peningkatan variabel pelatihan sebesar 1 satuan maka kinerja akan meningkat sebesar 0,395. Sedangkan besarnya pengaruh pelatihan diketahui melalui penghitungan koefisien determinasi $\left(r^{2}\right)=27,7 \%$, artinya kinerja pegawai dipengaruhi $27,7 \%$ oleh pelatihan sedangkan sisanya $72,3 \%$ ditentukan oleh faktor lain.

\section{KESIMPULAN DAN SARAN}

\section{Kesimpulan}

Berdasarkan hasil penelitian dan pembahasan, maka dapat disimpulkan bahwa ada pengaruh pelatihan terhadap kinerja pegawai Sub Bagian Keuangan Dinas Pekerjaan Umum dan Penataan Ruang Kabupaten Lampung Selatan, dimana berdasarkan uji-t didapatkan nilai thitung yaitu $=3,558$. Apabila dibandingkan dengan tTabel pada taraf nyata $95 \%$ dan $\alpha=0,05$ yaitu 1,697 maka 
thitung $=3,558>$ tTabel $=1,697$. Hasil penelitian menunjukkan persamaan regresi $\mathrm{Y}=23,991+0,395 \mathrm{X}$, jika terjadi peningkatan variabel pelatihan sebesar 1 satuan maka kinerja akan meningkat sebesar 0,395, Sedangkan besarnya pengaruh pelatihan diketahui melalui penghitungan koefisien determinasi $\left(r^{2}\right)=$ $27,7 \%$, artinya kinerja pegawai dipengaruhi $27,7 \%$ oleh pelatihan.

\section{Saran}

Berdasarkan simpulan di atas, maka dapat diberikan saran antara lain:

1. Bagi Dinas Pekerjaan Umum dan Penataan Ruang Kabupaten Lampung Selatan diharapkan semakin meningkatkan dan menumbuhkan pelatihan di kalangan pegawai.

2. Menjelaskan kepada pegawai akan pentingnya tujuan dari adanya proses pelatihan kerja, dimana untuk memudahkan pegawai agar dapat memahami segala hal yang dibutuhkan dalam bekerja.

\section{DAFTAR PUSTAKA}

Ahmad. 2013. Strategi Pengembangan Manajemen Sumber Daya Manusia. Yogyakarta: Pustaka Pelajar.

Arikunto, Suharsimi. 2012. Prosedur Penelitian: Suatu Pendekatan Praktik. Jakarta: Rineka Cipta.

Dessler. 2013. Manajemen Sumber Daya Manusia. Jakarta: : Rineka Cipta.

Fandy \& Anastasia, 2013, Perencanaan dan Pengembangan Sumber Daya Manusia. Bandung: Alfabeta.

Ghozali. 2011. Aplikasi Analisis Multivariate Dengan Program
SPSS. Semarang: Badan Penerbit Universitas Diponegoro.

Handoko. 2013. Manajemen Personalia \& Sumberdaya Manusia, Edisi Pertama. Yogyakarta: BPFE UGM.

Hasibuan, Malayu S.P. 2013. Manajemen Sumber Daya Manusia. Edisi Kesatu. Jakarta: Bumi Aksara.

Mangkunegara, Anwar Prabu. 2013. Manajemen Sumber Daya Manusia. Jakarta: Salemba Empat.

Rivai dan Sagala. 2014. Manajemen Sumber Daya Manusia Perusahaan. Jakarta: Rajawali.

Sadili, Samsudin. 2013. Manajemen Sumber Daya Manusia. Jakarta: Gunung Agung.

Sedarmayanti. 2015. Sumber Daya Manusia dan Produktivitas Kerja. Jakarta: Mandar Maju.

Septian, Reza. 2012. Pengaruh Pelatihan Terhadap Kinerja Karyawan ERHA Clinic Bandung. Jurnal Penelitian.

Siagian. 2013. Manajemen Sumber daya Manusia. Jakarta: Bumi Aksara.

Sugiyono. 2013. Metode Penelitian Pendidikan Pendekatan Kuantitatif, kualitatif, dan $R \& D$. Bandung: Alfabeta.

Veithzal, Rivai. 2012. Manajemen Sumber Daya Manusia (Human Resource), Bandung: Alfabeta.

Wahyudi. 2013. Manajemen Sumber Daya Manusia, Cetakan Kedua. Jakarta: Rajawali. 